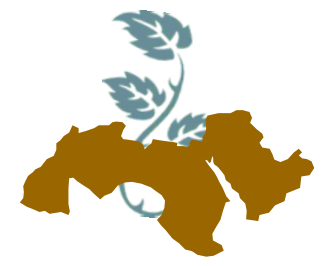

\title{
GROWTH PERFORMANCE OF SEA BASS FRY (DICENTRARCHUS LABRAX) UNDER DIFFERENT SALINITIES
}

\author{
Elaraby', M.E.; M.F.Osman²; M.A. Abdel-Baky² and \\ T.A. Aboelmakarem² \\ 1- General Authority for Fish Resources Development (GAFRD), Ministry of Agric., and Land \\ Reclamation, Giza, Egypt \\ 2- Fish Production Div., Animal Production Dept., Fac. of Agric., Ain Shams Univ., Cairo, Egypt
}

Keywords: European Sea Bass, Salinities, Performance

\section{ABSTRACT}

This study aimed to investigate the effect of different concentrations of different water salinity $(36,17,8,4,2$ ppt. and salinity level is less than 1 ppt.) on growth performance and survival rate (\%) of sea bass fry Dicentrarchus labrax. One thousand and two hundred sea bass fry were randomized stocked at twelve indoor tanks; $4 \mathrm{~m}^{3}$ each (two replicate/treatment), with an average initial body weight of $(2 \pm 0.30 \mathrm{~g} / \mathrm{fish})$ at the rate of 100 fish / tank. Fish in each tank were hand-fed with commercial diet (40\% crude protein and 485.582 Kcal GE/ $100 \mathrm{~g}$ diet). Fish were fed daily at a rate of $15,10,5,4$ and $3 \%$ of the body weight daily for the $(1: 2.2) ;(2.2: 3.84) ;(3.84: 9.2) ;(9.20: 12.70)$ and (12.70) $\mathrm{g} /$ fish : until the end of the experiment, respectively. The daily allowances were divided into three meals at $8.00 \mathrm{am} ; 11.00 \mathrm{am}$ and $2.00 \mathrm{pm}$. Fish were fed six days a week throughout the experimental period (167 days). The daily amount of feed was re-adjusted every two weeks according to the actual fish biomass in the tanks. The highest significant values of growth performance parameters were observed when sea bass fry were reared at salinities 8 and 36 ppt. Weight gain of the other treatments were negatively affected $(p<0.05)$ by water salinity. The lowest growth performance parameter was observed by salinity level less than 1 ppt. The highest FCR (1.64) recorded at 8 ppt. compared with (1.73) at $36 \mathrm{ppt}$. and worsens (1.91) at salinity level of less than 1ppt. The same trend was observed for protein efficiency ratio and condition factor where sea bass fry $D$. labrax reared at water salinity 8 ppt. recorded the highest value (1.45 and 1.16), respectively, while treatment 6 (less than 1 ppt. salinity) showed the lowest significant $(P<0.05)$ values $(1.31$ and 1.01$)$, respectively. No mortality was recorded during the experimental period in all treatments. The economic returns studies showed that the total return and net profit were linked to the prices of the raw materials used in the experiment as well as the marketing prices of the fish produced. Total return and net profit showed that the fish reared at 8 ppt. achieved the highest economic return followed by the 36 ppt. and 17 ppt., while treatment 6 (less than 1 ppt.) showed the lowest economic return followed by 4 ppt. Since the feeding cost of these two treatments is $16 \%$ higher than the other treatments, which affected the economic returns. However, when evaluating the situation as a high value fish species (like sea bass) with economic value reared in fresh water, this yield is very favorable in terms of cost compared to the selling price.

\section{INTRODUCTION}

The European sea bass (Dicentrarchus labrax (Linnaeus 1758)) is typically a marine species which spend most of its life in coastal lagoons and estuaries, although it has been observed occasionally in rivers (3ppt. to full strength sea water). It inhabits waters ranging from hypersaline to brackish, and shows oceanodromous behavior. Its euryhaline and eurythmic capability permits this species to show a wide geographic range of distribution and a wide depth range, occurring from shallow waters $(2-10 \mathrm{~m})$ to more than $100 \mathrm{~m}$. It is distributed in the Eastern Atlantic, from Norway to Senegal, and in the Mediterranean and Black Sea. 
It has been introduced for culture purposes in Israel, and more recently in Oman and the United Arab Emirates (Haffray et al 2007). D. labrax inhabit at temperatures between $8^{\circ} \mathrm{C}-24^{\circ} \mathrm{C}$ (Froese and Pauly 2012), although it has been reported that they tolerate temperatures from $5^{\circ} \mathrm{C}$ in the northern Mediterranean coastal lagoons, such as Thau, to $27^{\circ} \mathrm{C}$ in the lagoon of Biban in Tunisia (Barnabé 1986), or even up to $32^{\circ} \mathrm{C}$ (Barnabé 1990). It tolerates a wide range of salinities, however, can't tolerate freshwater (Zanuy and Carrillo, 1985; Eroldoğan and Kumlu, 2002; Eroldoğan et al 2004; Eroldoğan et al 2005; Di Trapani et al 2014). Under natural conditions, reproduction always occurs in marine habitats. From the larva/juvenile transition and beyond (mean length $\sim 15 \cdot \mathrm{mm}$ ), a fraction of the juvenile cohorts of $D$. labrax enters the brackish waters of the lagoons and estuaries, where they spend most of their early life (Kelley et al 1988; Pickett and Pawson, 1994). Juveniles and adults seasonally concentrate at river mouths and in coastal lagoons, and some individuals are known to migrate several km up rivers to freshwater (FW; $5-15 \mathrm{mOsmol} \cdot \mathrm{kg}^{-1}$; Barnabé and Guissi, 1993). Adaptation to various levels of salinity, including FW, involves coordinated physiological responses based on the function of several osmoregulatory organs. It is well established that adult euryhaline teleosts are able to maintain its blood osmolality at about 300-350 $\mathrm{mOsmol} \cdot \mathrm{kg}^{-1}$ in the range of tolerable salinities, due to an effective hydro-mineral regulation occurring mainly at the gill, urinary system, intestine and integument levels (Evans et al 1999; Greenwell et al 2004; Varsamos et al 2001).

The objectives of this study were thus: (1) Evaluate the growth performance of pre-fattening sea bass Dicentrarchus labrax at different water salinities; (2) To determine different abilities of osmoregulation at salinity less than 1 ppt. compared with other salinity levels; and (3) Economical evaluation of sea bass Dicentrarchus labrax cultivation by using different water resources available under Egyptian conditions.

\section{MATERIALS AND METHODS}

The present experimental work has been carried out in K21 Marine hatchery belongs to General Authority for Fish Resources Development (GAFRD), Al-Agami, Alexandria, Egypt.

\section{Experimental Facility and design}

Before starting the experiment, tanks was drained completely, disinfected by chlorine then cleaned by fresh water several time and were exposed to sun radiation for two days. The experimental fiberglass tanks were distributed randomly to six treatments each treatment was replicated in two tanks $\left(4 \mathrm{~m}^{3}\right.$ water volume / tank). Acclimation was done for approximately 15 days by lowering the salinity with fresh water until the desired salinity levels (36, 17, 8, 4, 2 and <1 ppt.) were reached. Throughout the study, sea water was mixed daily with fresh water, and aerated with an air-blower connected to stone air-diffuser when all test salinities were adjusted with the refractometer. Sea Bass fry (Dicentrarchus labrax L., 1758) with average initial weight $(2.0 \pm 0.30) \mathrm{g} /$ fish were stocked at a rate of $25 \mathrm{fish} / \mathrm{m}^{3}$ (100 fish/tank).

\section{Experimental diets}

Composition and proximate analysis (\%) of commercial diet used in the study presented in (40 $\%$ protein and $485.58 \mathrm{kcal}$ GE/100g diet) (Table 1). Diet ingredients were the pellet size approximately was $0.3 \mathrm{~mm}$ in diameter and $2 \mathrm{~mm}$ in length. Fish in each tank were hand-fed with the experimental diet. The feeding rate were 15, 10, 5 , 4 and $3 \%$ of the body weight daily for the $(1: 2.2)$; (2.2:3.84); (3.84: 9.2); (9.20:12.70) and (12.70) $\mathrm{g} / \mathrm{fish}$ to the end of the experiment, three times daily (8.00am ; 11am and $2.00 \mathrm{pm}$ ) for six days a week throughout the experimental period (167 days). The daily amount of feed was re-adjusted every two weeks according to the actual fish biomass in the tanks.

\section{Measurements of fish performance, survival rate and condition factor}

Samples were taken at stocking and at harvest to estimate the average daily gain (ADG, $\mathrm{g} /$ fish/day), specific growth rate (SGR, \%/day), protein efficiency ratio, feed conversion ratio, survival rate and condition factor were calculated according to the following formula:

1- Average daily gain (ADG) $=F W-I W / T$

Where: Fw: mean weight at the end of the experiment

Iw: mean weight at the beginning of the experiment

$\mathrm{T}$ : time in days 
2- Specific growth rate (SGR $\% /$ day) $=100$ $(\ln F w-\ln / w) / T$

Where: Fw: mean weight at the end of the experiment

Iw: mean weight at the beginning of the experiment

T: time in days (Jauncey and Ross, 1982)

3- Protein efficiency ratio $(P E R)=$ weight gain(g/fish)/protein intake, (Bagenal, 1978).

4- Feed conversion ratio $(F C R)=$ feed intake / weight gain, (Jhingran, 1991).

5- Fish survival rate $(\%)=100(\mathrm{Fn} / \mathrm{In})$

Where: Fn: number of fish at the end of the experiment

In: number of fish at the beginning of the experiment (Akatsu et al 1983).

6- Condition factor $(K)=100^{*}\left(\mathrm{~W} / \mathrm{L}^{3}\right)$

Where: W: Final mean body weight $(\mathrm{g})$. $\mathrm{L}$ : Mean standard length $(\mathrm{cm})$.

\section{Experimental Diet}

Experimental diet were prepared by using the local available raw material in market according to (NRC, 1993) (Table 1),

Table 1. Composition and Proximate analysis (\%) of commercial diet used in the study.

\begin{tabular}{|c|c|}
\hline Ingredient (\%) & $\%$ \\
\hline Fish meal $(72 \% \mathrm{CP})$ & 20.00 \\
\hline Soybean meal (44\% CP) & 45.00 \\
\hline Corn Gluten Meal & 7.00 \\
\hline Rice bran & 10.00 \\
\hline Yellow corn & 4.00 \\
\hline Vegetable oil & 10.10 \\
\hline Fish oil & 0.50 \\
\hline Salt & 0.50 \\
\hline $\mathrm{CaCO}_{3}$ & 1.00 \\
\hline Mono calcium sulphate & 0.50 \\
\hline Binder (Bintonite)® & 1.075 \\
\hline Anti-oxidant and Anti toxic & 0.025 \\
\hline Vitamin and mineral premix ${ }^{1}$ & 0.30 \\
\hline Total & 100.00 \\
\hline \multicolumn{2}{|l|}{ Chemical composition (\%) } \\
\hline Crude protein & 40 \\
\hline Ether extract & 15 \\
\hline Crude fiber & 4.8 \\
\hline Ash & 6.7 \\
\hline NFE (\%) & 28.6 \\
\hline Gross Energy (kcal / 100g diet) ${ }^{2}$ & 485.582 \\
\hline $\mathrm{P} / \mathrm{E}$ ratio ${ }^{3}$ & 82.37 \\
\hline
\end{tabular}

Table 2. Vitamins and minerals of the mixture used in the experimental diets $(/ \mathrm{kg})$

\begin{tabular}{|l|l|l|l|}
\hline \multicolumn{1}{|c|}{ Item } & $\begin{array}{l}\text { Unit } / \mathbf{~ k g} \\
\text { mixture }\end{array}$ & Item & $\begin{array}{l}\text { Unit } / \text { kg } \\
\text { mixture }\end{array}$ \\
\hline Vitamin A & $4.8 . \mathrm{I.u}$. & Folic acid & $400 \mathrm{mg}$ \\
Vitamin D3 & $0.8 . \mathrm{I.u}$. & Biotin & $20 \mathrm{mg}$ \\
Vitamin E & $4.0 \mathrm{gm}$ & $\begin{array}{l}\text { Choline } \\
\text { chloride }\end{array}$ & $200 \mathrm{mg}$ \\
Vitamin K & $0.8 \mathrm{gm}$ & Copper & $4.0 \mathrm{mg}$ \\
Vitamin B1 & $0.4 \mathrm{gm}$ & lodine & $0.4 \mathrm{mg}$ \\
Vitamin B2 & $1.6 \mathrm{gm}$ & Iron & $12.0 \mathrm{mg}$ \\
Vitamin B6 & $0.6 \mathrm{gm}$ & Manganese & $22.0 \mathrm{mg}$ \\
Vitamin B12 & $4.0 \mathrm{gm}$ & Zinc & $22.0 \mathrm{mg}$ \\
Pantothenic & $4.0 \mathrm{gm}$ & Selenium & $0.04 \mathrm{mg}$ \\
acid & $8.0 \mathrm{gm}$ & & \\
Nicotinic acid & 8.0 & \\
\hline
\end{tabular}

* Broiler premix was obtained from Pfizer , Egypt

\section{Water quality parameters}

Water quality parameters in the experimental circular fiberglass tanks were determined as follow:

The concentration of total ammonia-nitrogen was measured at weekly according to Boyd and Lichkoppler (1979).

Nitrite was monitored weekly using a model PLN code test kit from LaMotte (Chestertown, Maryland, USA).

Water temperatures were recorded daily in each circular fiberglass tanks. Also, dissolved oxygen was measured daily by oxygen meter and $\mathrm{pH}$ using $\mathrm{pH}$ meter. Water salinity was measured in different treatments daily by the refractometer.

Over the experimental period of 167 days, the temperature, oxygen, $\mathrm{pH}$, total ammonia-nitrogen (TA-N mg/l) and nitrite (NO2-N, mg/L) were (25.19 $\left.\pm 4.00^{\circ} \mathrm{C}\right) ;(7.18 \pm 0.7 \mathrm{mg} / \mathrm{l}) ;(6.8 \pm 0.2) ;(0.01 \pm 0.002$ $\mathrm{mg} / \mathrm{L})$ and $(0.13 \pm 0.002 \mathrm{mg} / \mathrm{L})$ respectively.

\section{Economical study}

Economical analysis was done at the end of the study. The total return (value of fish harvest), total costs (value of fingerlings, artificial diets, and water exchange cost), and the net estimated return [total return- total costs] were calculated according to (Green et al 1995).

\section{Statistical analysis}

The statistical analysis was applied according to Steel and Torrie (1980) on the collected data using a SAS program (1998). Differences between means were tested for significance according to Duncan's multiple rang test (Duncan, 1955). 
The following model was used to analyze the obtained data:

\section{$Y i j=u+T i+e i j$}

Where:

$$
\begin{aligned}
& Y i j=\text { observation. } \\
& U=\text { the overall mean. } \\
& \mathrm{Ti}=\text { the effect of treatment. } \\
& \text { eij= random error. }
\end{aligned}
$$

\section{RESULTS}

\section{Growth parameters}

The effects of different salinity levels (DSL) on growth performance of pre-fattening sea bass $(D$. labrax) were summarized in Table 3.

Growth performance of sea bass fry D.labrax reared in water salinity at $8 \mathrm{ppt}$. had higher value than those at normal salinity $36 \mathrm{ppt}$. (42.75 g/fish) (Table 3) and were significantly affected by water salinity $(p<0.05)$. The highest final weights were displayed at 8 ppt. (44.25 g/fish), 17 ppt. (39.90 $\mathrm{g} / \mathrm{fish})$ and $4 \mathrm{ppt}$. (38.25g/fish), respectively. The fish reared in 2 ppt. (35.5 g/fish and $<1$ ppt. (31.10 $\mathrm{g} / \mathrm{fish}$ ) had the second best weight at the end of the experiment, respectively. Average daily gain at $<1,8$ and 36 ppt. were $0.18,0.26$ and 0.25 $\mathrm{g} /$ fish/day, respectively. Specific growth rates at $<1$ and 36 ppt. were lower than those displayed at salinity below 8 ppt. (Table 3 and Fig. 1). The specific growth rates at $<1,8$ and 36 ppt. were $1.63,1.81$ and 1.79 , respectively.

\section{Feed utilization parameters}

The effect of different salinity levels on feed utilization parameters and condition factor of sea bass $D$. labrax were summarized in Table 4 and Fig. 2. Feed conversion ratio improves at salinity level 8 ppt. (1.64) compared with normal salinity level 36 ppt. (1.73) and were significantly affected by water salinity $(p<0.05)$ followed to salinity levels at 17 ppt. (1.73), 4 ppt. (1.71), 2ppt (1.74) respectively, and worsens at salinity level of less than 1 ppt (1.91). Protein efficiency ratio of sea bass $D$. labrax fry reared in water salinity at 8 ppt. ( 1.52) had higher value than those at normal salinity 36 ppt. (1.45) (Table 4) and were significantly affected by water salinity $(p<0.05)$, while the lowest value recorded when fish reared in $>1$ ppt. (1.31). The same trend was observed for the condition factor where sea bass fry $D$. labrax reared in water salinity at 8 ppt. recorded the highest value (1.16) with significant differences $(P \leq 0.05)$ with other treatments, while the lowest significant one $(P<0.05)$ was recorded (1.01) treatment 6 where is salinity less than $1 \mathrm{ppt}$.

\section{Economical Evaluation}

The effect of different salinity levels on total income and net return of sea bass fry $D$. labrax were summarized in Table 5. The total income and net return were related greatly to the cost of inputs materials, which used in this study and to marketing price of the product.

Sea bass fry $D$. labrax reared in water salinity at 8 ppt. achieved the highest net return than 36 ppt. and 17 ppt., while the lowest net return was shown by salinity at $<1 \mathrm{ppt}$. then salinity at 2 ppt., it increased about $16 \%$ in the amount of feed comparing at $8 \mathrm{ppt}$. (the best result), but compared to use fresh water for cultivate valuable fish like Sea bass it is an important result.

Table 3. Effect of different salinity levels (DSL) on growth performance of sea bass fry (D. labrax).

\begin{tabular}{|c|c|c|c|c|c|}
\hline \multirow{2}{*}{$\begin{array}{c}\text { DSL } \\
\text { ( ppt. ) }\end{array}$} & \multicolumn{2}{|c|}{ Body weight } & \multirow{2}{*}{$\begin{array}{c}\text { Total weight } \\
\text { gain (g/fish) }\end{array}$} & $\begin{array}{c}\text { ADG } \\
\text { (g/fish/day) }\end{array}$ & $\begin{array}{c}\text { SGR } \\
\text { (\%/day) }\end{array}$ \\
\cline { 2 - 5 } & Initial (g/fish) & Final (g/fish) & & \\
\hline 36 & 2.15 & $42.75^{\mathrm{b}} \pm 0.25$ & $40.60^{\mathrm{a}} \pm 0.20$ & $0.25^{\mathrm{a}} \pm 0.001$ & $1.79^{\mathrm{a}} \pm 0.01$ \\
17 & 2.40 & $39.90^{\mathrm{bc}} \pm 0.10$ & $37.50^{\mathrm{b}} \pm 0.10$ & $0.23^{\mathrm{b}} \pm 0.002$ & $1.68^{\mathrm{ab}} \pm 0.06$ \\
8 & 2.15 & $44.25^{\mathrm{a}} \pm 0.75$ & $42.10^{\mathrm{a}} \pm 0.75$ & $0.26^{\mathrm{a}} \pm 0.001$ & $1.81^{\mathrm{a}} \pm 0.03$ \\
4 & 2.20 & $38.25^{\mathrm{cd}} \pm 0.0 .25$ & $36.05^{\mathrm{bc}} \pm 0.0 .25$ & $0.22^{\mathrm{bc}} \pm 0.002$ & $1.71^{\mathrm{bc}} \pm .0 .05$ \\
2 & 2.25 & $35.50^{\mathrm{d}} \pm 0.50$ & $33.25^{\mathrm{d}} \pm 0.50^{\mathrm{c}}$ & $0.20^{\mathrm{d}} \pm 0.001$ & $1.65^{\mathrm{c}} \pm 0.02$ \\
$<1$ & 2.05 & $31.10^{\mathrm{c}} \pm 0.90$ & $29.05^{\mathrm{d}} \pm 0.95$ & $0.18^{\mathrm{d}} \pm 0.001$ & $1.63^{\mathrm{d}} \pm 0.04$ \\
\hline
\end{tabular}

$a, b, \ldots$. etc., mean in the same column bearing different superscript are significantly different at $(P<0.05)$.

${ }^{1} \mathrm{ADG}=$ Average daily gain ( $\mathrm{g} /$ fish/day)

${ }^{2} \mathrm{SGR}=$ Specific growth rate $(\% /$ day $)$ 


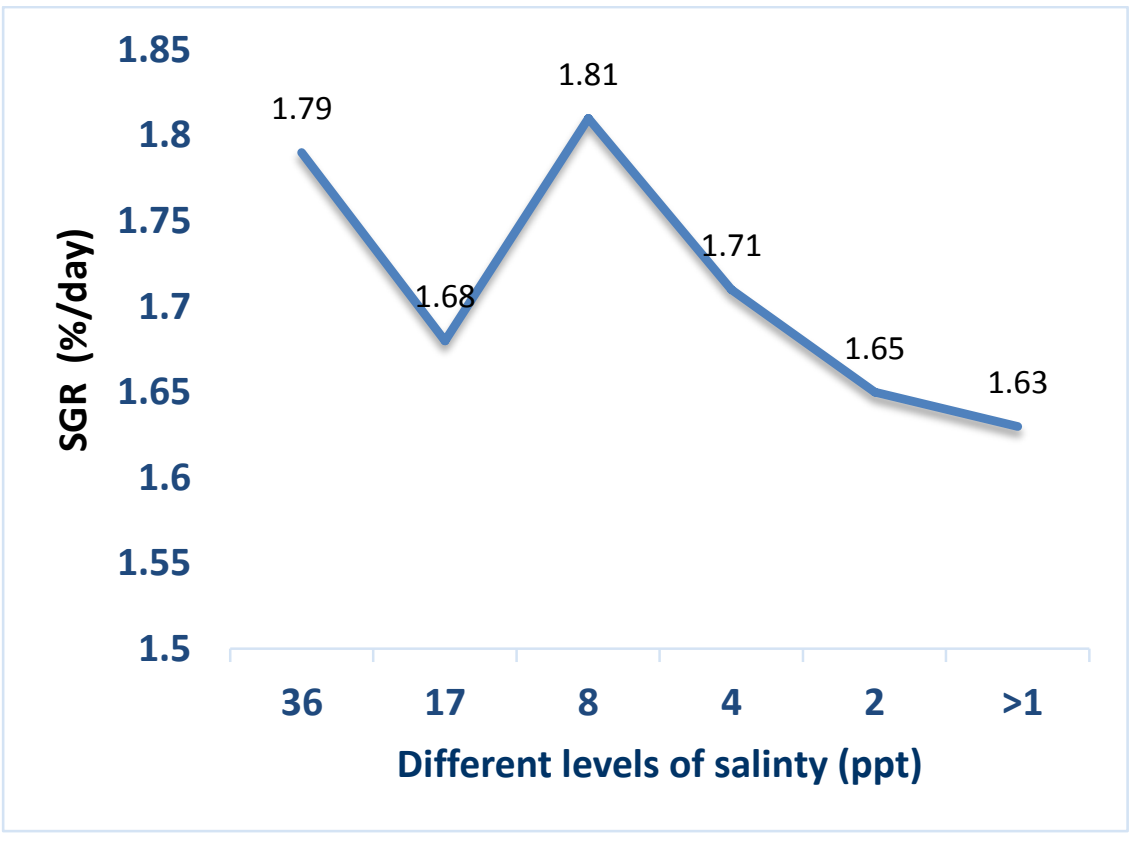

Fig. 1. Effect of different salinity levels on specific growth rate (\%/day) of sea bass fry (D. labrax)

Table 4. Effect of different salinity levels (DSL) on feed utilization parameters of sea bass (D. labrax) fry.

\begin{tabular}{|c|c|c|c|c|c|c|}
\hline $\begin{array}{c}\text { DSL } \\
\text { (ppt })\end{array}$ & FI & FCR & PER & FBW & FBL & K \\
\hline 36 & $70.24 \pm 4.85$ & $1.73^{\mathrm{ab}} \pm 0.01$ & $1.45 \pm 0.01$ & $42.75^{\mathrm{b}} \pm 0.25$ & $15.59^{\mathrm{a}} \pm 0.13$ & $1.13 \pm 0.02$ \\
$\mathbf{1 7}$ & $64.88 \pm 4.83$ & $1.73^{\mathrm{ab}} \pm 0.09$ & $1.45 \pm 0.01$ & $39.90^{\mathrm{bc}} \pm 0.10$ & $15.59^{\mathrm{a}} \pm 0.13$ & $1.09 \pm 0.02$ \\
$\mathbf{8}$ & $69.04 \pm 4.84$ & $1.64^{\mathrm{b}} \pm 0.01$ & $1.52 \pm 0.03$ & $44.25^{\mathrm{a}} \pm 0.75$ & $15.59^{\mathrm{a}} \pm 0.13$ & $1.16 \pm 0.03$ \\
$\mathbf{4}$ & $61.29 \pm 4.67$ & $1.71^{\mathrm{ab}} \pm 0.02$ & $1.47 \pm 0.02$ & $38.25^{\mathrm{cd}} \pm 0.0 .25$ & $15.59^{\mathrm{a}} \pm 0.13$ & $1.10 \pm 0.02$ \\
\hline$<$ & $57.86 \pm 4.56$ & $1.74^{\mathrm{ab}} \pm 0.03$ & $1.44 \pm 0.02$ & $35.50^{\mathrm{d}} \pm 0.50$ & $15.59^{\mathrm{a}} \pm 0.13$ & $1.07 \pm 0.01$ \\
\hline
\end{tabular}

a,b, ....etc., mean in the same column bearing different superscript are significantly different at $(P<0.05)$. $\mathrm{FI}=$ Feed intake; FCR = Feed conversion ratio; $\mathrm{PER}=$ Protein Efficiency Ratio,

$F B W=$ Final body weight; $F B L=F i n a l$ body length and $K=$ condition factor. 


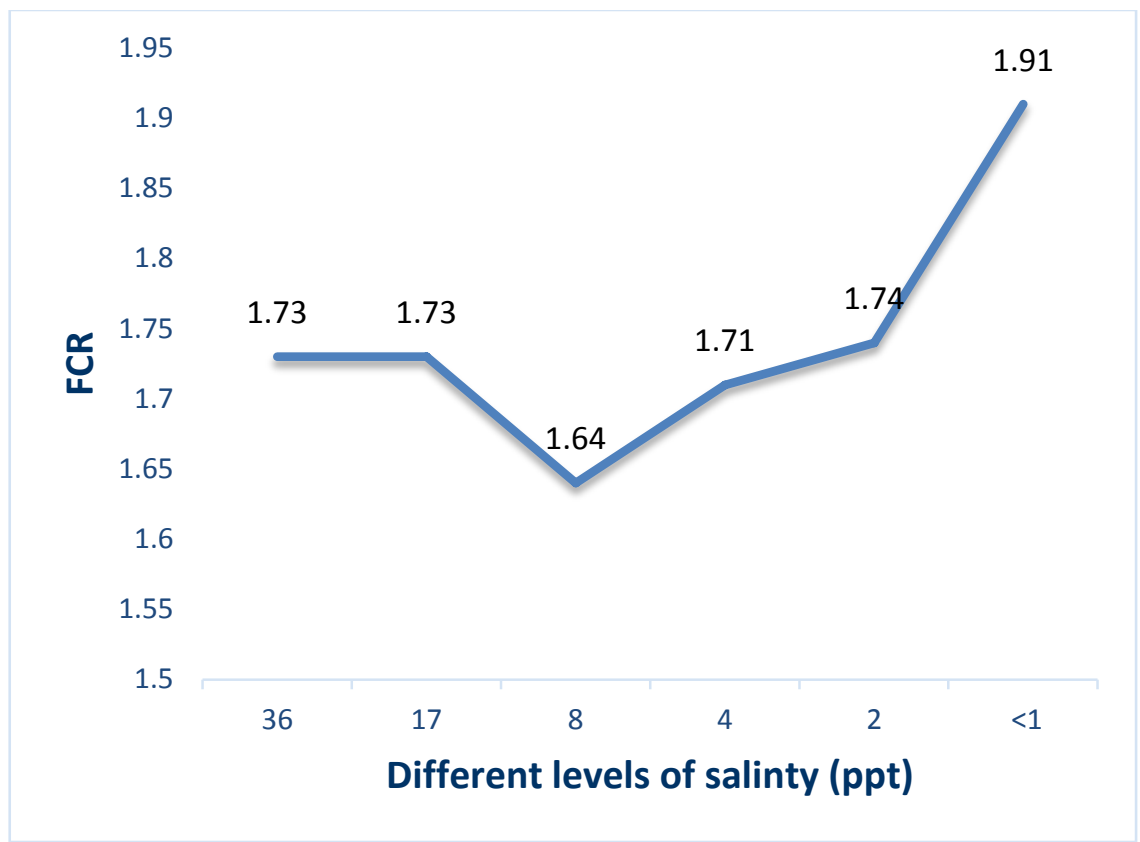

1.20

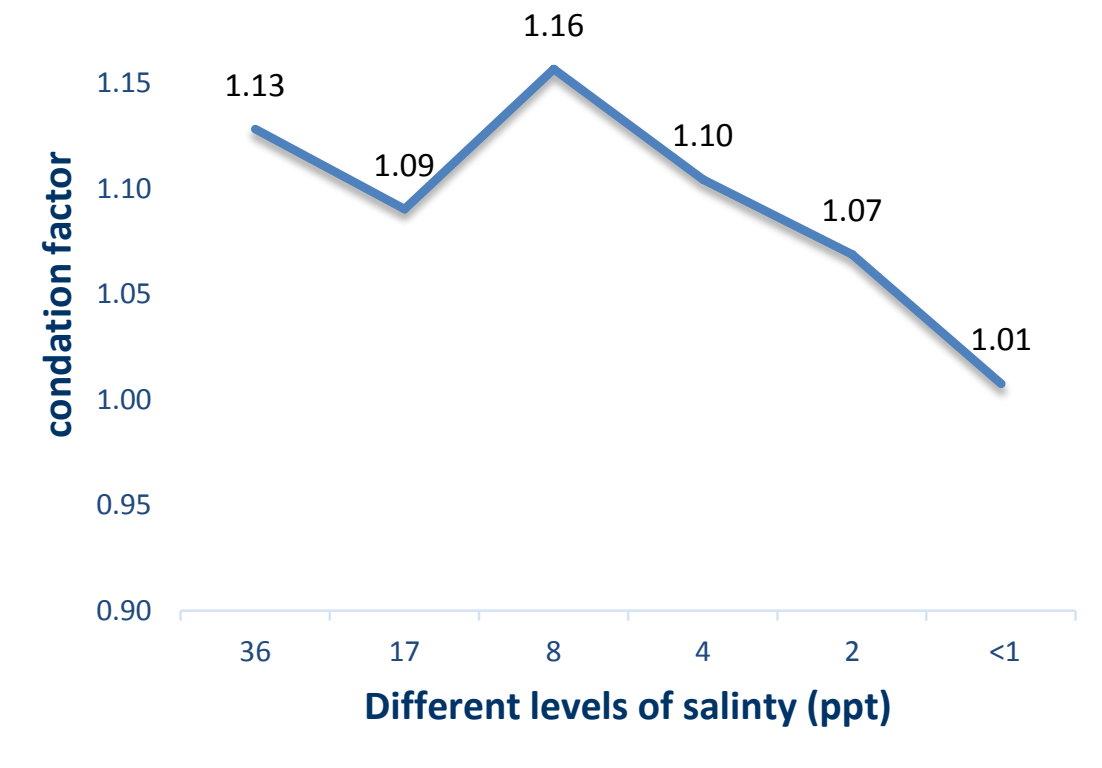

Fig. 2. Effect of different salinity levels on feed conversion ratio and condition factors of sea bass fry (D. labrax). 
Table 5. Effect of different salinity levels (DSL) on economical evaluation parameter of sea bass $(D$. labrax) fry;

\begin{tabular}{|c|c|}
\hline $\begin{array}{c}\text { DSL } \\
\text { (ppt.) }\end{array}$ & $\begin{array}{c}\text { Economical } \\
\text { Evaluation }\end{array}$ \\
\hline 36 & $68.96^{\mathrm{a}} \pm 1.01$ \\
17 & $64.46^{\mathrm{a}} \pm 1.01$ \\
8 & $70.73^{\mathrm{a}} \pm 1.01$ \\
4 & $62.56^{\mathrm{b}} \pm 1.01$ \\
2 & $57.28^{\mathrm{c}} \pm 1.01$ \\
$<1$ & $53.46^{\mathrm{c}} \pm 1.01$ \\
\hline
\end{tabular}

$a, b, \ldots$ etc., mean in the same column bearing different superscript are significantly different at $(P<0.05)$.

\section{DISCUSSION}

The results of growth performance and feed utilization parameter were in agreement with several authors like; Dendrinos and Thorpe, (1985); Conides and Glamuzina, (2006); Rubio et al (2005), who found different growth rates and different feed conversion ratios when different environmental conditions were applied. Their results showed that salinity levels between 25-30 ppt. were the optimum for the growth rate of European sea bass. They specifically recorded that $18 \mathrm{ppt}$. salinity level at $19^{\circ} \mathrm{C}$ provided optimum conditions for feed intake and growth performance. These results are closely consistent with the findings found in the present study. All of the aforementioned studies also stated that the fish need more energy for osmoregulatory process at low salinity levels. However, whether or not all sea-bass are able to adapt long-term to fresh water is still unclear; as described by different experimental studies (Cataudella et al 1991; Allegrucci et al 1994; Jensen et al 1998; Lemaire et al 2000; Varsamos et al 2002). Also sharing opinion of Eroldoğan and Kumlu, (2002) who stated that; juvenile and young sea bass were not only able to survive successfully in fresh water but could also grow well in the medium salinity. Also our results agreed with the results of Ercan et al (2015) who found that the highest growth performance was achieved when European Sea Bass fish reared in10 ppt. water salinity. Our results do not agree with the findings of Dendrinos and Thorpe (1985) who observed an immediate loss of appetite and heavy mortality in fish gradually acclimated to fresh water over a period of two weeks. They found that fish growth rate was decreased in the order of decreasing water salinities. Further attempts by Eroldoğan and Kumlu (2002) to acclimatize European sea bass fish into fresh water again failed. In the present study, however, neither juvenile nor young fish had any difficulty in acclimation to fresh water, hence, euryhaline capability does not seem to be affected by fish size, confirming the suggestion of Jensen et al (1998). It is difficult to see why there is a clear difference in tolerance to fresh water between the sea bass stocks used by Dendrinos and Thorpe (1985) and those used in our experiment. It is known that inherent differences to salinity tolerance exist in shrimp populations located in different parts of the world Harpaz and Karplus (1991) and Kumlu and Jones (1995). This type of environmental adaptation may also be true for different geographical strains in fish. In fact, a difference in tolerance to salinity has already been suggested between the European sea bass populations inhabiting marine and lagoon ecosystems Kumlu and Jones (1995). It was also found that hatchery juveniles tolerate direct transfer to low salinities better than wild juveniles Marino et al (1994). Also not partly agreed with Bernardino and Fernandes (2016) who said that; after two months of study, there was no growth differences in different salinities, meaning that fish grew in a similar way in salinities 3,6 and 12, 5. Further studies are necessary in order to access growth in a longer period.

\section{CONCLUSION}

In general, the results of this study indicate that it can use different levels of salinity for sea bass Pre-fattening stage with the advanced growth performance in brackish water (salinity 8 ppt.) up to sea water, feed utilization and increase economical return. The present study gives the opportunities to the marine hatchery to sell Sea bass fingerlings to brackish water farms to produce high value fish species like Sea bass (Dicentrarchus labrax L., $1758)$, which is reflect on the sustainability of investment opportunities in aquaculture sector using a different levels of salinity.

\section{REFERENCES}

Akatsu, S., Al-Abdul-Elah, K.M. and Teng, S.K. 1983. Effects of salinity and water temperature on the survival and growth of brown-spotted grouper larvae (Epinephelus tauvina, Ser- 
ranidae). J. World Maric. Soc. 14, 624-635.

Allegrucci, G.C., Fortunato, C.S. and Sbordoni, V. 1994. Acclimatation to fresh water of the seabass: evidence of selective mortality of allozyme genotypes. In Genetics and Evolution of Aquatic Organism (ed. Beaumont A.R.), pp. 487-502. Chapman \& Hall. London, UK.

Bagenal, T. 1978. Method for assessment of fish production in fresh waters. Third edition. IBP Handbook No 3. Blackwell scientific publication. Oxford. $365 \mathrm{p}$.

Barnabé, G. 1986. L'elevage du loup et de la daurade. pp. 627-666. In: Aquaculture. Barnaba G. and Silbard, Y. (eds.). Technique et Documentation, Lavoisier, Paris. 2, 1123 p..

Barnabé, G. 1990. Rearing bass and gilthead bream. pp. 647-686. In G. Barnabé (ed.) Aquaculture, Ellis Horwood, Sussex, England. 2, $1104 \mathrm{p}$.

Barnabe, G. and Guissi, A.1993. Combined effects of diet and salinity on European sea bass larvae Dicentrarchus labrax. J. World Aquacult. Soc., 24, 439-450.

Bernardino, R.J. and Fernandes, C. 2016. Growth performance for European sea bass fingerlings, Dicentrarchus labrax, reared at different salinities. Front. Mar. Sci., Conference Abstract: IMMR International Meeting on Marine Research, Peniche, Portugal, 14 Jul - 15 Jul, doi: 10.3389/conf.FMARS.2016.04.00031.

Boyd, C.E. and Lichkoppler, F. 1979. Water quality management in pond fish culture. Auburn Univ., Alabama, International for Aquaculture Agric. Exp. Station Research and Development Series, No. 22, 30 p.

Cataudella, S., Allegrucci, G., Bronzi, P., Cataldi, E., Cioni, C., Corti, M., Crosetti, D., De Merich, D., Fortunato, C. and Garibaldi, L. 1991. Multidisciplinary approach to the optimization of sea bass (Dicentrarchus labrax) rearing in freshwater - Basic morpho-physiology and osmoregulation. Aquacult. Env. 14, 56-57.

Conides, A.J. and Glamuzina, B. 2006. Laboratory simulation of the effects of environmental salinity on acclimation, feeding and growth of wild-caught juveniles of European sea bass Dicentrarchus labrax and gilthead sea bream, Sparus aurata. Aquaculture, 256, 235-245.

Dendrinos, P. and Thorpe, J.P. 1985. Effects of reduced salinity on growth and body composition in the European sea bass Dicentrarchus labrax (L.). Aquaculture, 49, 333-358.

Di Trapani, A.M., Sgroi, F., Testa, R. and Tudisca, S. 2014. Economic comparison between offshore and inshore aquaculture production systems of European sea bass in Italy. Aquaculture 434, 334339.

Duncan, D.B. 1955. Multiple range and multiple Ftests. Biomet. 11, 1-42.

Ercan E., Ağralı, N. and Tarkan, A.S. 2015. The Effects of Salinity, Temperature and Feed Ratio on Growth Performance of European Sea Bass (Dicentrarchus labrax L., 1758) in the Water Obtained Through Reverse Osmosis System and a Natural River. Pakistan J. Zool., 47(3), 625-633.

Eroldoğan, O.T. and Kumlu, M. 2002. Growth performance, body traits and fillet composition of the European sea bass (Dicentrarchus labrax) reared in various salinities and freshwater. Turk. J. Vet. Anim. Sci. 26, 993-1001.

Eroldoğan, O.T., Kumlu, M. and Aktas, M. 2004. Optimum feeding rates for European sea bass Dicentrarchus labrax $L$. reared in seawater and freshwater. Aquaculture 231, 501-515.

Eroldoğan, O.T., Kumlu, M. and Aktas, M. 2005. Acclimation of European Sea bass (Dicentrarchus labrax) to freshwater and determination of its optimal feeding rates in freshwater. Aquaculture Research, 36, 361-369.

Evans, D.H., Piermarini, P.M. and Potts, W.T.W. 1999. Ionic transport in the fish gill epithelium. J. Exp. Zool., 283, 641-652.

Froese, R. and Pauly, D. Editors. 2012. Fish Base. World Wide Web electronic publication, version (12/2012). Accessed December 1, 2012 at http://www.fishbase.org.

Green, B.W., El-Nagdy, Z., Hebicha, H., Shaker, I., Kenawy, D.A.R. and El-Gamal, A.R. 1995. Evaluation of Nile Tilapia Production Systems in Egypt. CRSP Research Report pp. 91-95.

Greenwell, M., Sherrill, J. and Clayton, L. 2004. Osmoregulation in fish. Mechanisms and clinical implications Vet. Clin. Exot. Am., 6, 169189.

Haffray, P., Tsigenopoulos, C. S., Bonhomme, F., Chatain, B., Magoulas, A., Rye, M., Triantafyllidis, A. and Triantaphyllidis, C. 2007. European sea bass, Dicentrarchus labrax. Genetic Impact of Aquaculture Activities on Native Populations, Final Scientific Report. pp. 40-46.

Harpaz, S. and Karplus, I. 1991. Effects of salinity on growth and survival of juvenile Penaeus semisulcatus reared in the laboratory. Israel $\mathbf{J}$. Aquaculture - Bamidgeh. 43(4), 156-163.

Jauncey, K. and Rose, B. 1982. A guide to tilapia feeds and feeding. Institute of Aquaculture, University of Sterling, Scotland, 111 p. 
Jensen, M.K., Madsen, S.S. and Kritiansen, K. 1998. Osmoregulation and salinity effects on the expression and activity of $\mathrm{Na}+, \mathrm{K}+-$ ATPase in the gills of European sea bass, Dicentrarchus labrax (L.). J. Exp. Zool. 282, 290-300.

Jhingran, V.G. 1991. Fish and Fisheries of India, 3rd ed. Hindustan Publishing Corporation, Delhi, India, 727 p.

Kelly M., Burke, J., Smith, M.K.A. and Beach, D. 1988. Four mating-type genes control sexual differentiation in the fission yeast. EMBO J. 7(5), 1537-1547.

Kumlu, M. and Jones, D.A. 1995. Salinity tolerance of hatchery-reared postlarvae of Penaeus indicus $\mathrm{H}$. Milne Edwards originating from India. Aquaculture. 130, 287-296.

Lemaire, M., Xie J., Meisterernst, M., Collart, MA. 2000. The NC2 repressor is dispensable in yeast mutated for the Sin $4 p$ component of the holoenzyme and plays roles similar to Mot1p in vivo. Mol Microbiol 36(1), 163-73.

Marino, G., Cataldi, E., Pucci, P.I., Bronzi, P. and Cataudella, S. 1994. Acclimation trials of wild and hatchery sea bass (Dicentrarchus labrax) fry at different salinities. J. Appl. Ichthyol. 10, 57-63.

NRC, 1993. Nutrient requirements of Warm Iszi£i Fishes Shellfishes. National Rresearch Council, National Academy Press. Washington DC, USA. 102 p.
Pickett, G.D. and Pawson, M.G. 1994. Biology and ecology. In Sea Bass: Biology, Exploitation and Conservation (ed. Pitcher, T.J.), pp. 9-146. London: Chapman \& Hall.

Rubio, V.C., Sanchez-Vazquez, F.J. and Madrid J.A. 2005. Effects of salinity on food intake and macronutrient selection in European sea bass. Physiol. Behav., 85, 333-339.

SAS. 1998. Statistics. SAS Institute Inc. editors, Cary, NC.

Steel, R.G.D. and Torrie, J.A. 1980. Principles and procedures of statistics. $2^{\text {nd }}$ ed., USA McGraw Hill, pp. 183-193.

Varsamos, S., Connes, R., Diaz, J. P., Barnabé, G. and Charmantier, G. 2001. Ontogeny of osmoregulation in the European sea bass $\mathrm{Di}$ centrarchus labrax L. Mar. Biol. 138, 909-915.

Varsamos, S., Diaz, J.P., Charmantier, G., Flik, G., Blasco, C. and Connes, R. 2002. Branchial chloride cells in sea bass (Dicentrarchus labrax) adapted to fresh water, seawater, and doubly concentrated seawater. J. Exp. Zool. 293, 12-26.

Zanuy, S. and Carrillo, M. 1985. Annual cycle of growth, feeding rate, gross conversion efficiency and hematocrit levels of sea bass (Dicentrarchus labrax L.) adapted to two different osmotic media. Aquaculture 44, 11- 25. 